\title{
Responses of leaf colouring in four deciduous tree species to climate and weather in Germany
}

\author{
Nicole Estrella*, Annette Menzel \\ Chair of Ecoclimatology, Technical University Munich, Am Hochanger 13, 85354 Freising, Germany
}

\begin{abstract}
The annual timing of leaf colouring of deciduous trees in temperate regions is not predictable using phenological models. In this analysis we show that commonly applied hypotheses of leaf colouring triggers have neither satisfactory explanatory power nor significant statistical proof. We tested meteorological parameters, such as monthly mean temperatures, threshold temperatures, monthly sums of precipitation and number of dry days per month of the year of the phenological event and of the previous year and the length of the vegetation period. Their influence on leaf colouring dates for 4 deciduous tree species (horse chestnut, beech, birch, oak) in Germany (1951-2003) was tested by Pearson's correlations. We created 3 different datasets: (A) phenological observations for single stations within $25 \mathrm{~km}$ of meteorological stations, (B) means of phenological observations around $(<25 \mathrm{~km})$ meteorological stations, and $(\mathrm{C})$ phenological means for Germany. Only the mean temperature of September had a slight influence on the onset of leaf colouring (mean: $r_{\text {chestnut }}=0.45$; $\mathrm{r}_{\text {beech }}=0.56 ; \mathrm{r}_{\text {oak }}=0.51 ; \mathrm{r}_{\text {birch }}=0.45$ ). Taking all correlation coefficients $\mathrm{r}>10.31$ into account, we can deduce that a warm September (all species) and August (oak, birch) delayed leaf colouring while a warm June (horse chestnut, oak) and May (horse chestnut) advanced leaf colouring.
\end{abstract}

KEY WORDS: Response - Leaf colouring · Autumn phenology · Growing season · Vegetation period · Germany $\cdot$ Climate change

Resale or republication not permitted without written consent of the publisher

\section{INTRODUCTION}

There is an abundance of evidence that the global climate has changed in recent decades and that this change has had an influence on natural resources (IPCC 2001). Among the biological systems affected, phenology is one of the prominent bio-indicators of climate change, since the timing of recurring phenological events is altered by changed weather conditions. Significant correlations exist between winter/spring temperatures and spring phenological phases, such as bud burst, leaf unfolding or flowering in mid and higher latitudes (Menzel \& Estrella 2001, Sparks \& Menzel 2002, Walther et al. 2002, Menzel 2003, Root et al. 2003). Due to this statistical and causal relationship, it is possible to model the onset of these spring events, e.g. leaf unfolding (e.g. Hänninen 1990, Kramer 1995, Menzel 1997, Schaber 2002) or flowering (e.g. Chuine et al. 1999, 2003), based exclusively on temperature information as input.
In contrast, the causes of the timing of phenological events of deciduous plants in autumn, such as leaf colouring or leaf fall, are less understood. Theoretical knowledge exists about the triggering factors for leaf colouring and leaf fall of deciduous tree species. Trees shed their leaves in fall in order to reduce the evaporative surface area in winter and to avoid frost damage to leaves. The responsible chemical reactions are largely known: abscisic acid (ABA) and ethylene (as phytohormones) promote leaf fall by building the abscission zone at the base of the petiole. During the formation of the abscission zone, substances within the leaf which are useful for the plant are broken down and transferred to the woody parts of the tree (e.g. Koike 1990, Sitte et al. 2002).

There is some evidence that autumn phenological events may have been delayed in recent decades (e.g. Menzel \& Fabian 1999, Chmielewski \& Rötzer 2001), but these changes are less clearcut than their equiva- 
lents in spring and their pattern is far less homogenous (Menzel 2002, Sparks \& Menzel 2002). So far, no model framework exists to predict them. Some older studies even demonstrated that autumn phenological events were difficult to interpolate and map, as no consistent relationship with altitude, latitude and longitude existed (Schnelle 1979).

A few studies also report an observed lengthening of the growing season, defined as the time span between leaf unfolding and leaf colouring (e.g. Defila \& Clot 2001, Matsumoto et al. 2003). However, in order to interpret changes in the timing of autumn events or changes in the length of the growing season as effects of climate change and attribute them to explicit factors, it is necessary to develop a framework of how their timing is triggered, modified or altered by weather and climate conditions.

There are numerous hypotheses about weather or climate conditions modifying the onset of leaf colouring in temperate regions. In Table 1, common hypotheses are summarised. Some are vague and imprecise: Baumgartner (1950) stated that leaf colouring was induced by minimum temperatures, but he did not state the threshold temperature. Seyfert $(1955,1966)$ claimed that the timing of leaf colouring started later when there were warm temperatures and sufficient water supply in autumn. High radiation in autumn has been quoted as one of the causes of early leaf colouring; it might stimulate the production of assimilates, which cannot drain off and support the decomposition of chlorophyll (Seyfert 1970). Schulze (1970) argued in the same direction with high autumn temperatures quickening leaf colouring. Freitag (1987) tested mean June air temperatures and concluded that a warm June advanced, whereas a warm August and September temperatures delayed, the onset of leaf colouring, which is in contrast to Seyfert (1970) and Schulze (1970). Pfau (1964) postulated a constant length of the growing season which is defined as the period between the start of leaf unfolding until the onset of leaf colouring. Schnelle (1952) listed different thresh- old temperatures: as soon as the mean temperature in autumn dropped below $11^{\circ} \mathrm{C}$ leaf colouring was induced, after a drop below $10^{\circ} \mathrm{C}$ leaf colouring could be observed. The same stimulating effect would have minimum temperatures below 7 or $6^{\circ} \mathrm{C}$, where leaf colouring is again observable when the minimum temperature declines another degree. Hartmann \& Schnelle (1970) defined the vegetation period as the period when the mean temperature exceeded $8^{\circ} \mathrm{C}$ in a climate diagram. These and other more agriculturally based definitions (e.g. mean air temperature permanently above $5^{\circ} \mathrm{C}$ ) are only rough approximations, which do not consider the annual weather conditions. Therefore, we modified these hypotheses: the end of the vegetation period is induced when the daily mean temperature falls below the threshold temperature for a sequence of $5 \mathrm{~d}$. Further hypotheses about the influence of water availability were included in our analysis. Maede (1952) suggested that the soil water balance was influencing the onset of leaf colouring. By analysing different extended-range (general) weather situations (Grosswetterlagen), Seyfert (1955) stated that particularly synoptic types which led to declining soil water potential were responsible for an earlier onset of leaf colouring.

Most of the hypotheses described above (Table 1) have their origin in theoretical considerations or analyses of short time series of a few observed trees. In addition, most of them have never been verified on a statistically relevant dataset. Thus, the primary goal of this study was to test both the listed and some new hypotheses using a comprehensive meteorological and phenological dataset provided by the German Meteorological Service (DWD) before developing a model framework for autumn phenological events. The main aim was to identify meteorological parameters which trigger the onset of leaf colouring of deciduous trees and which might later be used in a statistical model. This is a major question, since the currently changing length of the growing season in temperate and boreal regions is mainly attributed to global warming and is

Table 1. Hypotheses of possible factors triggering the onset of leaf colouring ( ${ }^{*}$ re-examined in this study)

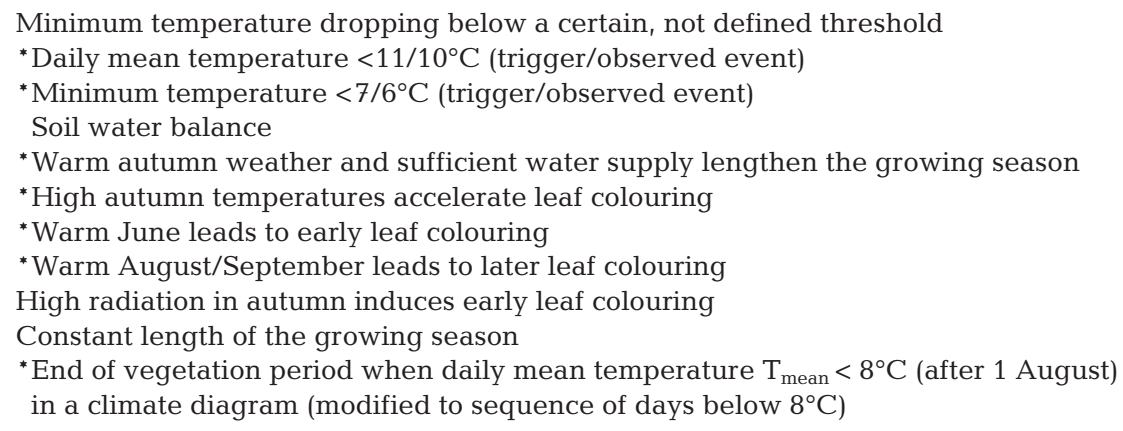

Baumgartner (1950)

Schnelle (1952)

Schnelle (1952)

Maede (1952)

Seyfert $(1955,1966)$

Schulze (1970)

Freitag (1987)

Freitag (1987)

Seyfert (1970)

Pfau (1964)

Hartmann \& Schnelle (1970) 
used as a high-quality indicator to track changes in the biosphere (EEA Report 2004). However, the length of the growing season depends not only on its wellunderstood start in spring, but also on its less understood end in autumn.

\section{MATERIALS AND METHODS}

\subsection{Climate data}

Meteorological data were provided by the German Meteorological Service (DWD). The data covered the time period from 1951 to 2003 and contained daily mean (Tm), maximum (Tmax) and minimum air temperature (Tmin) as well as daily precipitation at 54 stations (Fig. 1). Monthly mean temperatures, monthly sums of precipitation and the number of dry days per month were calculated for each climate station and year. In addition, national means for Germany of all variables were generated using data from all stations. As derived climatological variables, we determined for each meteorological station the first date (entry day) after 1 August with values below certain threshold temperatures: daily mean temperature of $11^{\circ} \mathrm{C}\left(\mathrm{FD}_{\text {mean }}\right.$ $<11), 9^{\circ} \mathrm{C}\left(\mathrm{FD}_{\text {mean }}<9\right), 8^{\circ} \mathrm{C}\left(\mathrm{FD}_{\text {mean }}<8\right), 7^{\circ} \mathrm{C}\left(\mathrm{FD}_{\text {mean }}<\right.$ $7)$ and $5^{\circ} \mathrm{C}\left(\mathrm{FD}_{\text {mean }}<5\right)$ and minimum temperature below $7^{\circ} \mathrm{C}\left(\mathrm{FD}_{\min }<7\right)$ and $5^{\circ} \mathrm{C}\left(\mathrm{FD}_{\min }<5\right)$. As such dates are strongly correlated, there was no need to test all other workable threshold temperatures.

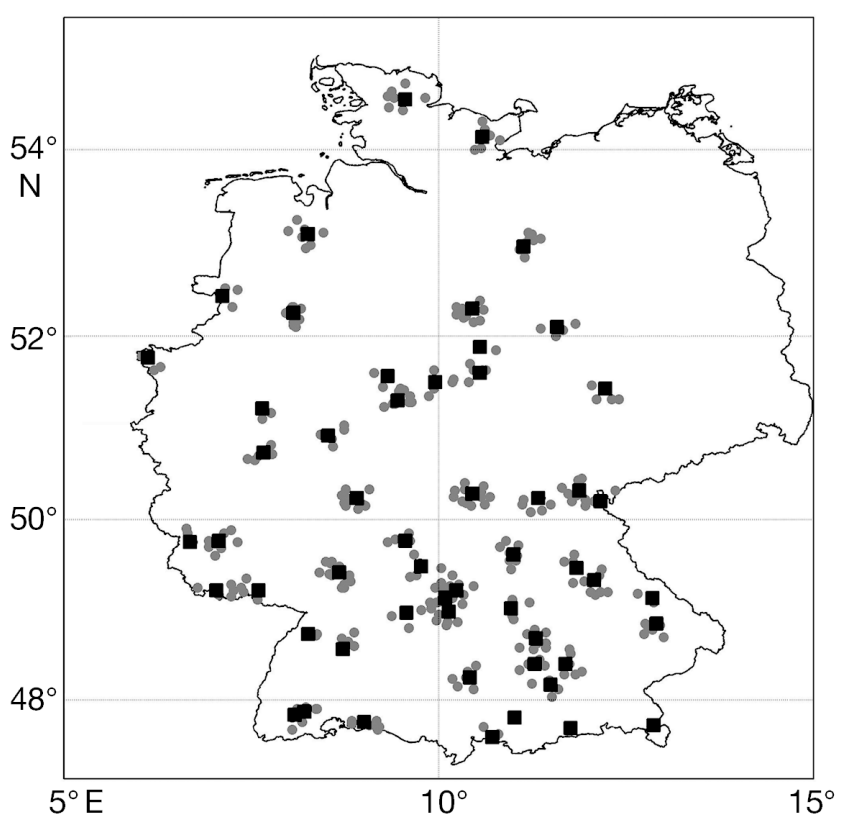

Fig. 1. Map of Germany with meteorological stations (squares) and phenological stations (circles) within $25 \mathrm{~km}$ distance (here for leaf colouring data of birch)

\subsection{Phenological data}

Out of the considerable dataset of phenological time series covering the time span from 1951 to 2003 in Germany, we selected the onset of leaf colouring in 4 deciduous tree species: horse chestnut Aesculus hippocastanum L., silver birch Betula pendula L., common oak Quercus robur L. and European beech Fagus sylvatica L. These phases are recorded throughout Germany by volunteers (ca. 1550 stations in 2004, maximum number of ca. 2500). Autumn colouring has to be recorded when $50 \%$ of all leaves (still on the tree or already fallen to the ground) show autumnal colouring (DWD 1991). The data were collected and qualitychecked by the German Meteorological Service. Three subsets were generated from the total phenological dataset. First, Set A contained phenological observations from single stations which were (1) situated within $25 \mathrm{~km}$, (2) within $50 \mathrm{~m}$ altitude of the meteorological stations (see 2.1, Fig. 1), and (3) whose phenological time series had to contain at least 15 yr of observations. For a second dataset (Set B) a phenological mean for each meteorological station was calculated from the surrounding phenological stations satisfying the first 2 criteria used in Set A (here even shorter time series of phenological observations were accepted). The third dataset (Set C) consisted of annual average phenological data of the 4 deciduous tree species for Germany. The number of phenological and climate stations used in each dataset is listed in Table 2. For a further detailed analysis of the plant responses to temperature, we selected long-term time series ( $>30 \mathrm{yr}$ ) of Set $\mathrm{A}$ and divided them into 2 groups: stations with a positive significant ( $5 \%$ level) trend in the observation period $(\mathrm{A}+$, equivalent to an observed delay in leaf colouring) and stations with a significant negative trend (A-). Fig. 2a shows the geographical variability of the mean onset of leaf colouring between 1951 to 2003 for Set B, Fig. 2b demonstrates an example of the interanual variations of birch for Set A and the year 1995.

\subsection{Methods}

For all 3 subsets, Pearson correlation coefficients (r) were calculated between the observed onset dates of leaf colouring and each meteorological parameter as well as derived variables (e.g. crossing of temperature thresholds) to test the hypotheses of Table 1 marked with an asterisk. For monthly mean temperatures we calculated correlations with leaf colouring both for the 'current' year, i.e. the year of observation, (e.g. mo_1 = January) and for the previous year (e.g. p_8 = August). Correlation coefficients were only calculated when $\mathrm{n}>16$. 
Table 2. Number of phenological (Phen) and climate (Clim) stations for each species and Sets A-C

\begin{tabular}{|c|c|c|c|c|c|c|c|}
\hline \multirow{2}{*}{ Species } & \multirow{2}{*}{ Common name } & \multicolumn{2}{|c|}{ Set A } & \multicolumn{2}{|c|}{ Set B } & \multicolumn{2}{|c|}{ Set $\mathrm{C}$} \\
\hline & & Phen & Clim & Phen & Clim & Phen & Clim \\
\hline Aesculus hippocastanum & Horse chestnut & 330 & 54 & 636 & 54 & 665 & 54 \\
\hline Fagus sylvatica & European birch & 292 & 53 & 604 & 53 & 629 & 53 \\
\hline Quercus robur & Common oak & 289 & 53 & 612 & 53 & 640 & 53 \\
\hline Betula pendula & Silver birch & 325 & 54 & 635 & 54 & 663 & 54 \\
\hline
\end{tabular}

\section{RESULTS}

\subsection{Effects of monthly mean temperature}

Correlation coefficients (r) between the onset of leaf colouring and monthly mean temperatures for all 3 datasets are shown in Fig. 3.

When analysing all phenological stations assigned to climate stations (Fig. 3a, Set A), the respective correlation coefficients of leaf colouring dates with mean monthly temperatures did not reveal consistent signs for single months. In contrast, they spread from large negative to large positive values for almost every month. Some single stations reached values up to -0.75 (birch mo_3) or 0.82 (birch mo_9); however, these were outliers.
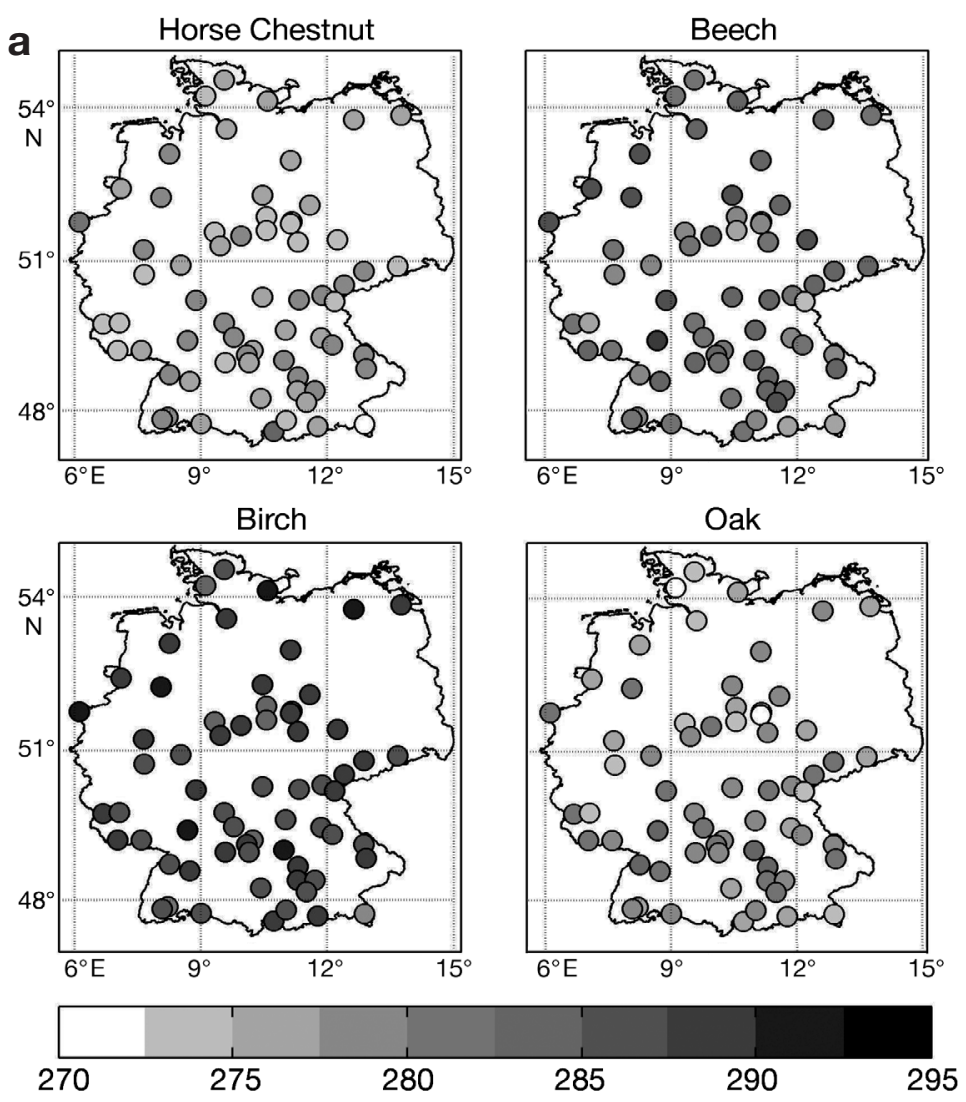

Fig. 2. (a) Mean onset (Day of the year) of leaf colouring (1951 to 2003) for Set B, and (b) onset of leaf colouring for birch in 1995 for Set A
Only the mean temperatures of September of the current year were predominantly positively correlated with leaf colouring dates. Thus, a warm September was associated with later leaf colouring. If only the 5th to 95th percentile range is considered, $\mathrm{r}$ varied between 0.48 and -0.17 (birch), 0.51 and-0.13 (horse chestnut), 0.56 and -0.08 (oak) and 0.58 and -0.10 (beech). August temperatures had a similar, but weaker influence; both warm August and September tended to delay leaf colouring.

For all species, predominantly negative correlations with mean temperatures for May of the current year existed, but there was a high variability among stations, even regarding the sign of the correlation. A similar effect of mean June temperatures with warm temperatures advancing leaf colouring dates was strongest for horse chestnut. Therefore, a temperature relationship with leaf colouring dates was apparent for the months of May, June, August and September. For all other months of the current and previous year, the correlation coefficients revealed a stochastic pattern of the influence of monthly mean temperatures.

In the next step, we reduced the spatial phenological variability by calculating annual means of

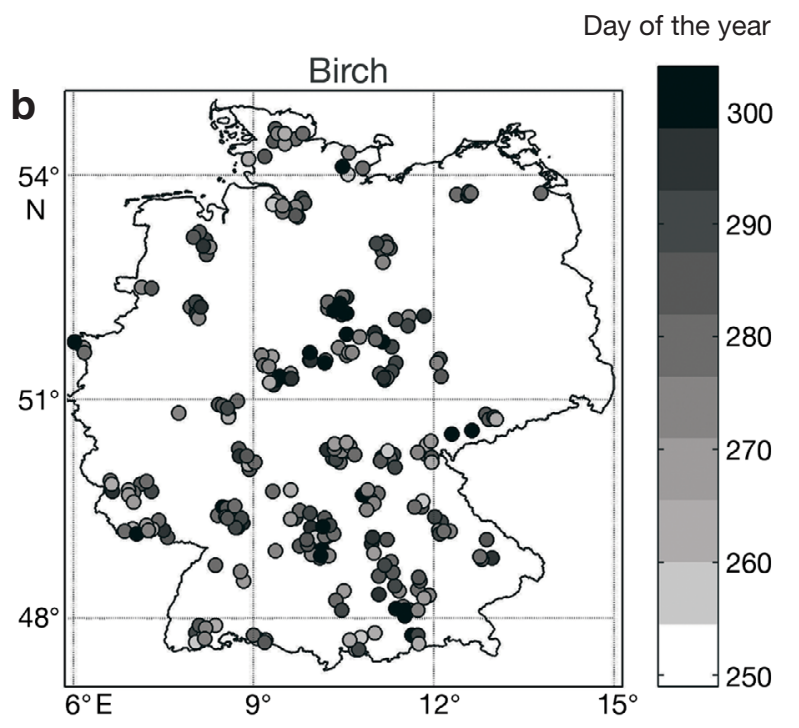


a
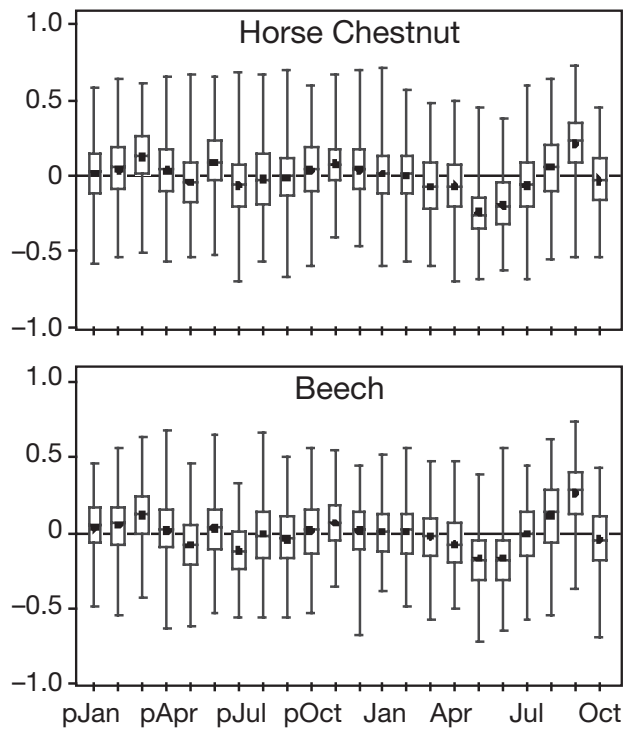

b

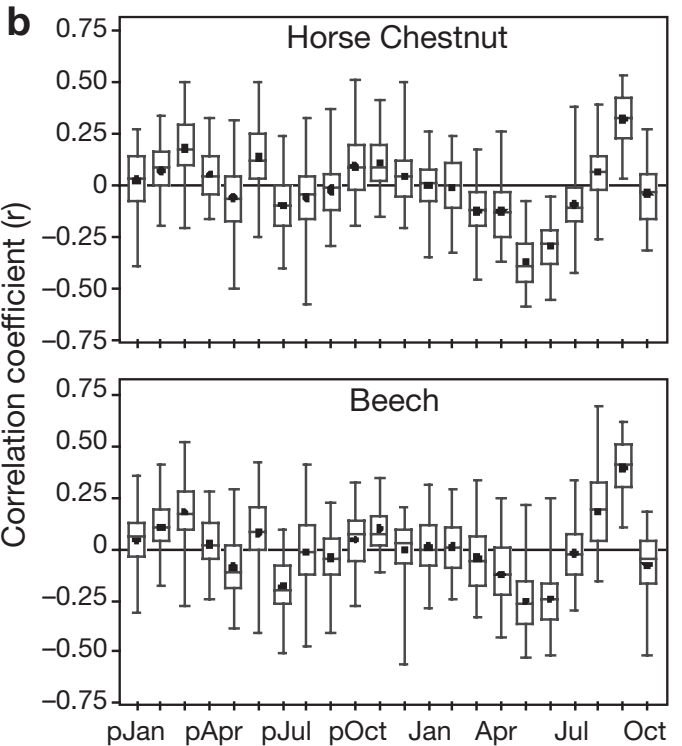

C
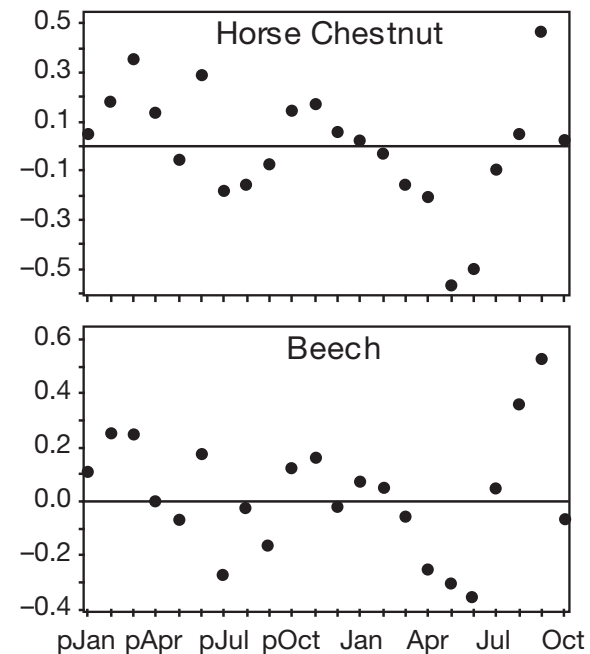
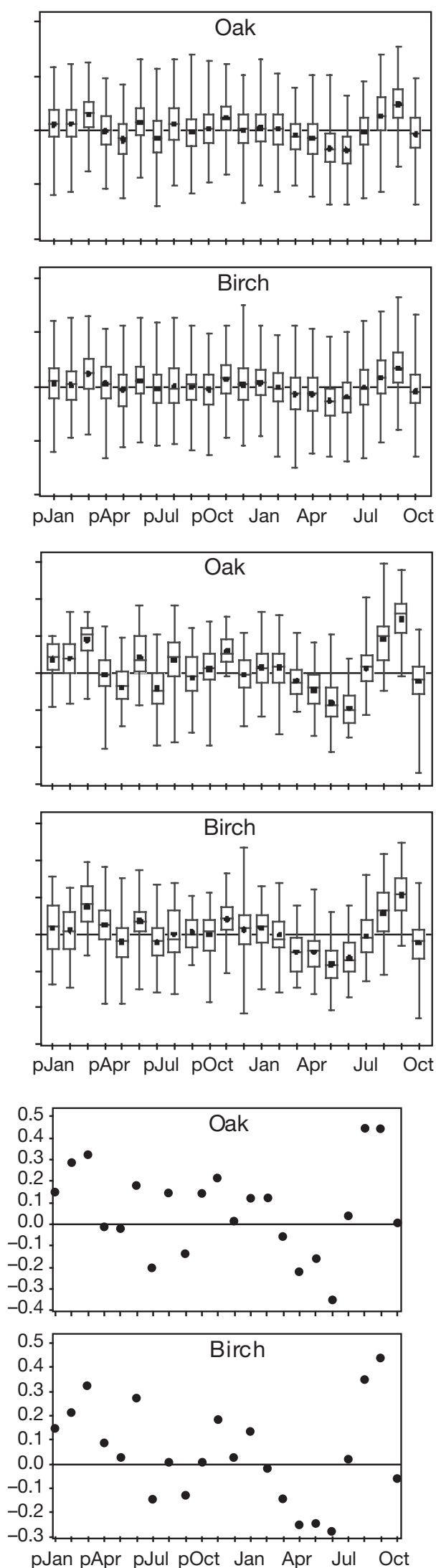

Fig. 3. Pearson correlation coefficients (r) of monthly mean temperatures ( $p=$ previous year) and the onset dates of leaf colouring. In boxes, = mean, horizontal line = median. (a) Set A: data of single phenological stations near meteorological stations, (b) Set B: spatially averaged phenological means near meteorological stations, and (c) Set C: national phenological means and national 
the onset dates of leaf colouring for all phenological stations near a meteorological station (Set B, Fig. 3b). In the respective scatterplots, it is quite obvious that the range and the absolute values of $\mathrm{r}$ were lower than for Set A. Extreme values for $r$ were reached in oak $(r=0.74$, mo_8 and $r=-0.67$, mo_10). As for Set A, August and September monthly mean temperatures showed a positive influence on the onset of leaf colouring for all species; the September effect was stronger. For horse chestnut and beech, all stations had positive correlation coefficients for August and September. Mean temperatures of May and June were mainly negatively correlated with leaf colouring dates; for horse chestnut this was true for all meteorological stations. The influence of the mean temperatures in May was stronger for horse chestnut, beech and birch, whereas oak reacted more to mean June temperatures.

In Set C, we used monthly mean temperature anomalies for Germany to calculate correlations between annual monthly temperatures and a national mean of leaf colouring for each species. Mean anomalies in May were negatively correlated with the onset of leaf colouring in horse chestnut $(\mathrm{r}=-0.60)$, this was the highest value of $\mathrm{r}$ for all species and months. Horse chestnut was further correlated with mean June ( $\mathrm{r}=$ -0.54) and September ( $r=0.45)$ temperature anomalies. For the 3 other species, mean September anomalies had the strongest influence on leaf colouring, ranging from 0.45 (birch) to 0.56 (beech). Birch ( $\mathrm{r}=$ $0.45)$ and oak $(r=0.39)$ leaf colouring dates also exhibited a positive relationship to March temperature anomalies of the previous year, which is difficult to interpret.

In general, the results of all 3 analyses concerning the influence of monthly temperature were comparable. Single station analysis (Set A) showed a vast range of $r$ and no consistency concerning the sign. Spatial averaging of the phenological response (Set B) led to a more regular pattern of the influence of the mean monthly temperature than for the single phenological stations, although the maximum values of $r$ were lower. However, there were still outliers in both directions, and, at most stations, the correlation coefficients between the onset of leaf colouring and the monthly mean temperature were often inconclusive $(\mathrm{r}<|0.2|)$. In the analysis of national phenological and climatological means, the influence of single months was reduced for all species. Taking all correlation coefficients $r>10.31$ into account, we can deduce that a warm September (all species) and August (oak, birch, beech) delayed leaf colouring, whereas a warm June (horse chestnut, beech, oak), May (horse chestnut, beech) and March of the previous year (horse chestnut, birch, oak) advanced leaf colouring.

\subsection{Effects of threshold temperature}

The impact of threshold temperatures on leaf colouring dates was tested for the 3 phenological Sets A-C. Fig. 4 displays the respective correlation coefficients between leaf colouring dates and the first day (FD) on which the air (mean or minimum) temperature falls below a defined threshold. These FDs can only have a triggering effect on leaf colouring if they occur earlier than autumnal colouring. This is true for all thresholds tested except $\mathrm{FD}_{\text {mean }}<5^{\circ} \mathrm{C}$, which occurs, on average, later than the mean onset of leaf colouring, but this threshold was retained as it is very commonly used to define the end of the vegetation period.

For Set A, it was quite apparent that even the signs of the correlation coefficients for single months were not identical at the various stations analysed. This was true for all species and months. The correlation coefficients ranged between $0.79\left(\mathrm{FD}_{\text {mean }}<11^{\circ} \mathrm{C}\right.$, beech) and $-0.77\left(\mathrm{FD}_{\text {mean }}<8^{\circ} \mathrm{C}\right.$, beech). The 5 th percentile values of $\mathrm{r}$ varied between $-0.36\left(\mathrm{FD}_{\text {mean }}<5^{\circ} \mathrm{C}\right.$, horse chestnut) and $-0.18\left(\mathrm{FD}_{\min }<5^{\circ} \mathrm{C}\right.$, oak), the 95 th percentile values between $0.51\left(\mathrm{FD}_{\text {mean }}<9^{\circ} \mathrm{C}\right.$, beech) and 0.35 ( $F D_{\text {mean }}<7^{\circ} \mathrm{C}$, horse chestnut). The results for the different thresholds were similar for all phases: there was hardly any relationship between the dates of crossing threshold temperatures and leaf colouring dates, only for beech and oak $\mathrm{FD}_{\text {mean }}<9^{\circ} \mathrm{C}$ is the interquartile range box clear of zero.

This pattern was similar in Set B: for all phases and thresholds the range of $r$ comprised positive as well as negative values. Oak and beech reached higher $\mathrm{r}$ values than horse chestnut and birch (e.g. beech maximum $\mathrm{r}=0.63, \mathrm{FD}_{\text {mean }}<8^{\circ} \mathrm{C}$ ). FDs and leaf colouring dates were predominantly positively correlated with leaf colouring dates, especially for $\mathrm{FD}_{\text {mean }}<7$ to $9^{\circ} \mathrm{C}$ (beech, oak) and $\mathrm{FD}_{\text {mean }}<9^{\circ} \mathrm{C}$ (horse chestnut, birch). This means that longer warm periods in summer and autumn delayed leaf colouring.

Set $\mathrm{C}$ revealed that most of the leaf colouring dates of oak and beech reacted to threshold temperatures. Oak reached the highest value with $\mathrm{r}=0.51$, followed by beech with $\mathrm{r}=0.46$ for $\mathrm{FD}_{\min }<5^{\circ} \mathrm{C}$. Birch reacted strongest on $\mathrm{FD}_{\min }<5^{\circ} \mathrm{C}$, but with $\mathrm{r}=0.40$ it was less significant than beech and oak. Leaf colouring of horse chestnut was least correlated to threshold temperatures (maximum $\mathrm{r}=0.39$ for $\mathrm{FD}_{\text {mean }}<9^{\circ} \mathrm{C}$ ).

\subsection{Effects of drought}

Soil water balance is thought to have an influence on the timing of leaf colouring (see Table 1). But the amount of water available to plants is also dependent on factors other than precipitation, such as soil type, 

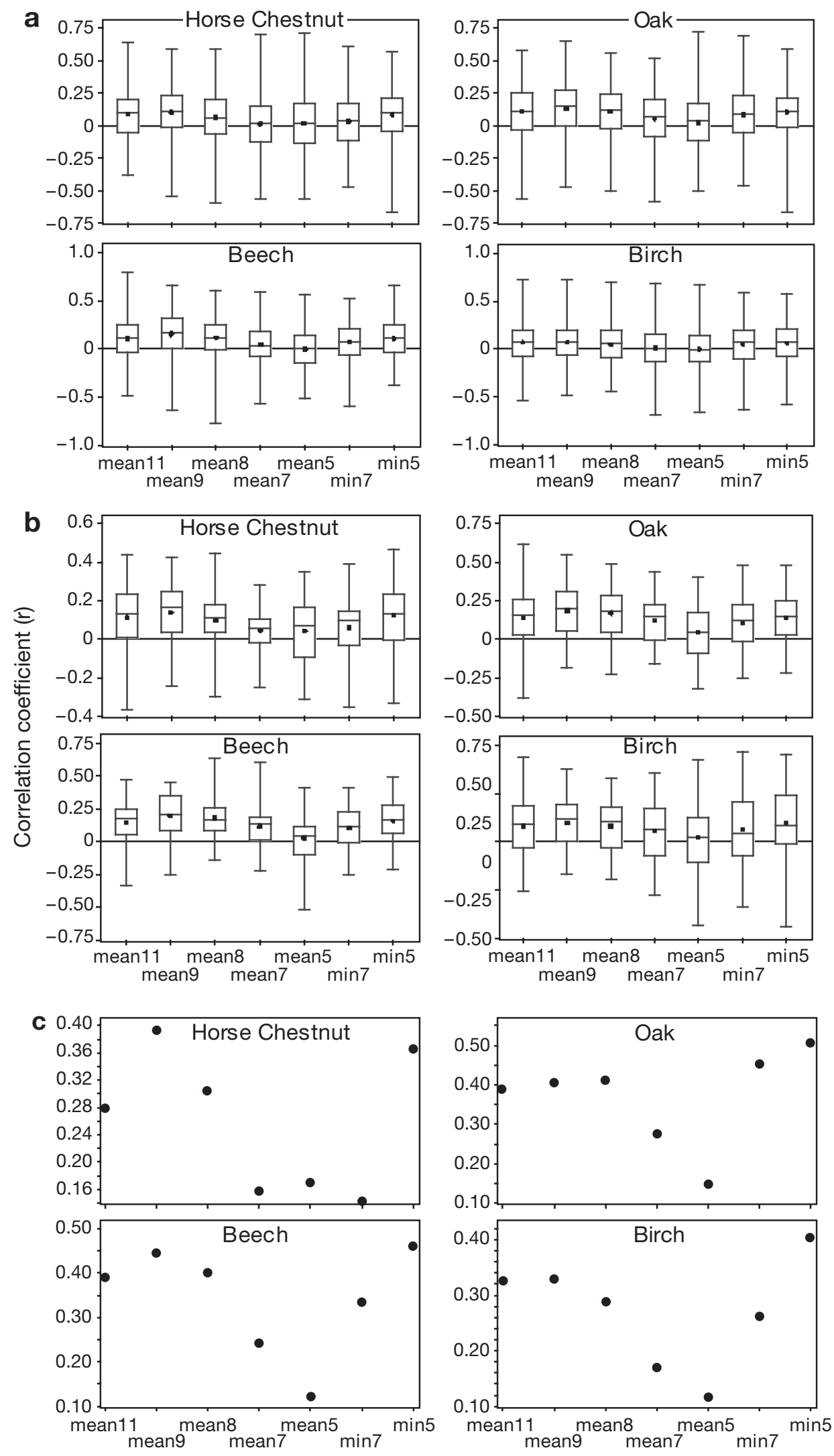

Fig. 4. Pearson correlation coefficients (r) of the first days (FD) on which the temperature drops below a threshold (mean11: $\mathrm{FD}_{\text {mean }}<11^{\circ} \mathrm{C}$, mean9: $\mathrm{FD}_{\text {mean }}<9^{\circ} \mathrm{C}$, mean8: $\mathrm{FD}_{\text {mean }}<8^{\circ} \mathrm{C}$, mean7: $\mathrm{FD}_{\text {mean }}<7^{\circ} \mathrm{C}$, mean5: $\mathrm{FD}$ mean $<5^{\circ} \mathrm{C}, \min 7=\mathrm{FD}_{\text {min }}<7^{\circ} \mathrm{C}$, min5: $\mathrm{FD}_{\min }<5^{\circ} \mathrm{C}$ ) and the onset dates of leaf colouring. In boxes, $=$ mean, horizontal line = median. (a) Set A: data of single phenological stations near meteorological stations, (b) Set B: spatially averaged phenological means near meteorological stations, and (c) Set C: national phenological means and national meteorological means 
slope and exposure. However, these important auxiliary data were not available for our phenological dataset, and they could not be deduced from other datasets, mainly because the exact location of the observed trees was unknown. Therefore we decided to use precipitation data in order to avoid unjustified assumptions about soil type or depth.

We tested monthly total precipitation and the number of dry days per month of both the current and the previous year. The coarse temporal resolution of monthly sums may lead to biased results. For example, storm rainfall events that can elevate monthly sums are predominantly direct runoff. As we wanted to treat precipitation and temperature effects separately, we did not create a humidity index to combine temperature and precipitation.

Neither of the hydrological parameters tested revealed meaningful correlations with onset dates of leaf colouring. For both Sets A and B, there was a wide range of positive and negative values of $r$. For example, for the monthly sums of precipitation (Set A, Fig. 5a) the range of $r$ for horse chestnut was always $>1$ (all mo), the smallest range of $\mathrm{r}(0.88)$ was for oak leaf colouring and monthly sums of precipitation in April of the current year.

For all 4 species and all months, the correlation coefficients displayed not only a large variability, but their means were also always $<|0.1|$. This indicates that the influence of monthly precipitation sums was negligible. For single phenological stations, there were very few significant correlation coefficients $>-0.7$ : e.g. for horse chestnut (January and May of the previous year, January, June, September and October of the current year), for beech (October of the previous year and July of the current year) and for oak (September of the previous year). The drier these months were, often in autumn of the previous year, the earlier leaf colouring took place at these particular stations. High correlation coefficients for birch leaf colouring and October and November precipitation sums of the current year $(0.72)$ at single stations demonstrate the problem of correlations tested on hundreds of time series; just by chance some are large even if the corresponding months clearly occur after leaf colouring.

Set B (Fig. 5b) displayed smaller ranges in $\mathrm{r}$ (mean range for all species and months 0.66 ). Only in 7 mo did we find a station with a correlation coefficient $>|0.5|$, the highest value $(-0.63)$ was for birch leaf colouring and March precipitation of the previous year.

Using Set C (Fig. 5c), only very small correlation coefficients were revealed: e.g. for horse chestnut $(r<|0.2|)$, for beech the largest $r$ were 0.29 (October of previous year) and -0.26 (August of the current year), similarly for oak 0.25 (June of previous year) and -0.29 (August of the current year) and for birch -0.30 (August of the current year). Thus, the only consistent trait in these scatterplots was a small indication that drier Augusts were related to later leaf colouring. This can be ascribed to the fact that a dry August is a proxy for a warm August (see Section 3.1).

The second indicator, number of dry days, exhibited slightly higher correlation coefficients than the monthly sums of precipitation (Fig. 6). Number of dry days were mainly negatively correlated to leaf colouring dates, which means that longer dry periods led to earlier leaf colouring. The most decisive months, identified in Set A (Fig. 6a), were June and July (horse chestnut) and April and May (beech) and, for Set B (Fig. 6b), June (all 4 species). This relatively strong influence of dry days in June on leaf colouring dates was also revealed in Set $C$ : horse chestnut $(r=-0.33)$, beech $(-0.24)$, oak $(-0.23)$ and birch $(-0.16)$. The drier the August the later leaf colouring took place for all species except horse chestnut (number of dry days: $\mathrm{r}_{\text {beech }}=0.23, \mathrm{r}_{\text {oak }}=0.26, \mathrm{r}_{\text {birch }}=0.20$ ).

\subsection{Length and end of vegetation period}

Various definitions of the end of the vegetation period exist, both meteorological as well as phenological. Common meteorological definitions are based on threshold temperatures, e.g. ongoing or temporary drop of mean air temperature below 5 or $10^{\circ} \mathrm{C}$ in the second half of the year. Biosphere models, which need the end of the vegetation period for deciduous trees in temperate regions as one parameter, generally apply a threshold temperature (e.g. IBIS $5^{\circ} \mathrm{C}$ threshold temperature; Foley et al. 1996), others use a combination of temperature and day length (e.g. BIOME BGC; White et al. 1997). The common simple definition of the length of the growing season by a specific time span, e.g. from 1 March until the end of October (Kärpäti \& Varga 1964) or, as used in forestry in Germany, from 1 May until the end of September (Hartmann \& Schnelle 1970) is not suitable for modelling purposes, as it does not allow for spatial or annual variability of leaf colouring dates. Hartmann \& Schnelle (1970) suggested a threshold temperature of $8^{\circ} \mathrm{C}$ for trees; however, they used the smoothed temperature curves in climate diagrams to define the start and the end of the vegetation period, which does not allow for interannual variations.

In order to reduce the influence of single extreme events, and to take yearly variations into account, we used a method where the vegetation period started when daily mean temperatures exceed $5^{\circ} \mathrm{C}$ for 7 consecutive days and ends as soon as the daily mean temperature fell below $5^{\circ} \mathrm{C}$ for 5 consecutive days (Arora $\&$ Boer 2005). We examined whether these indices 
a
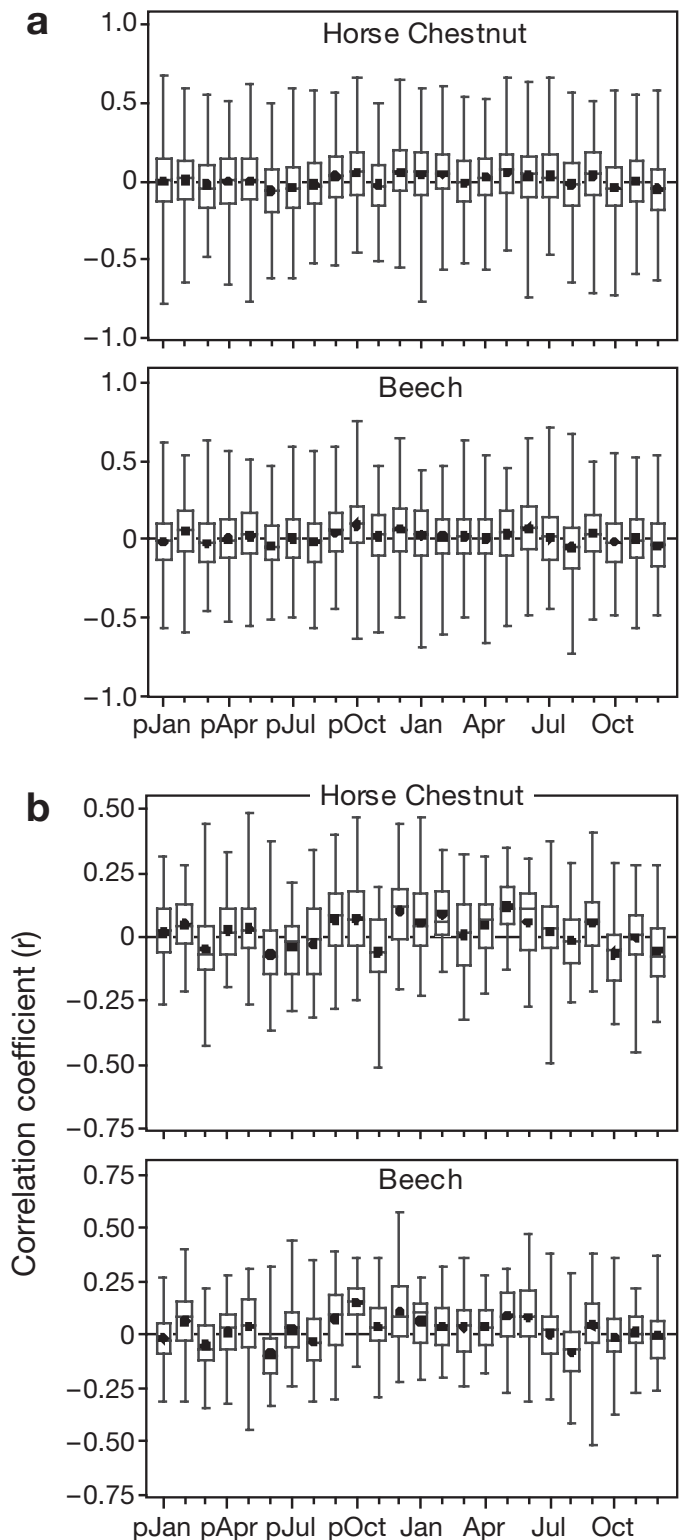

C

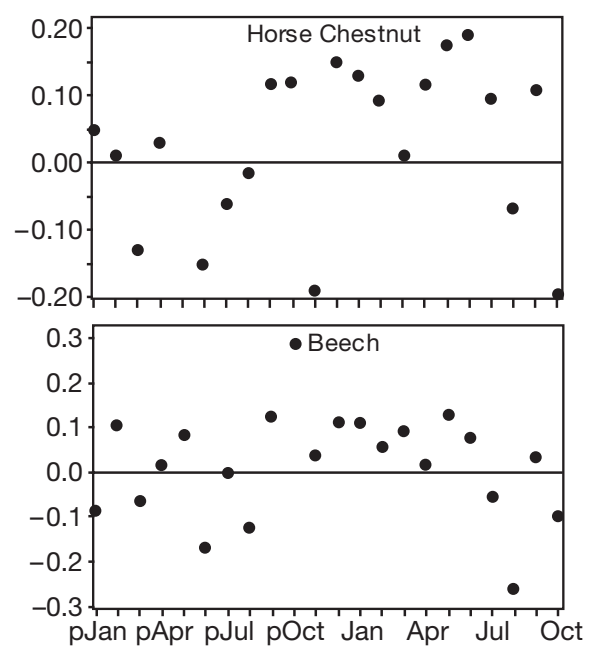

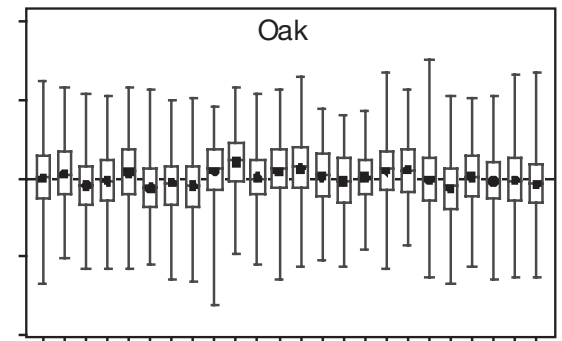

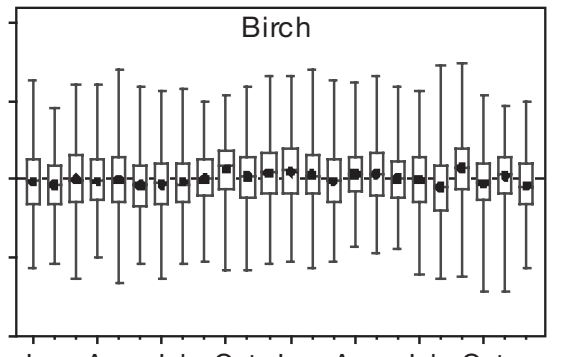

pJan pApr pJul pOct Jan Apr Jul Oct
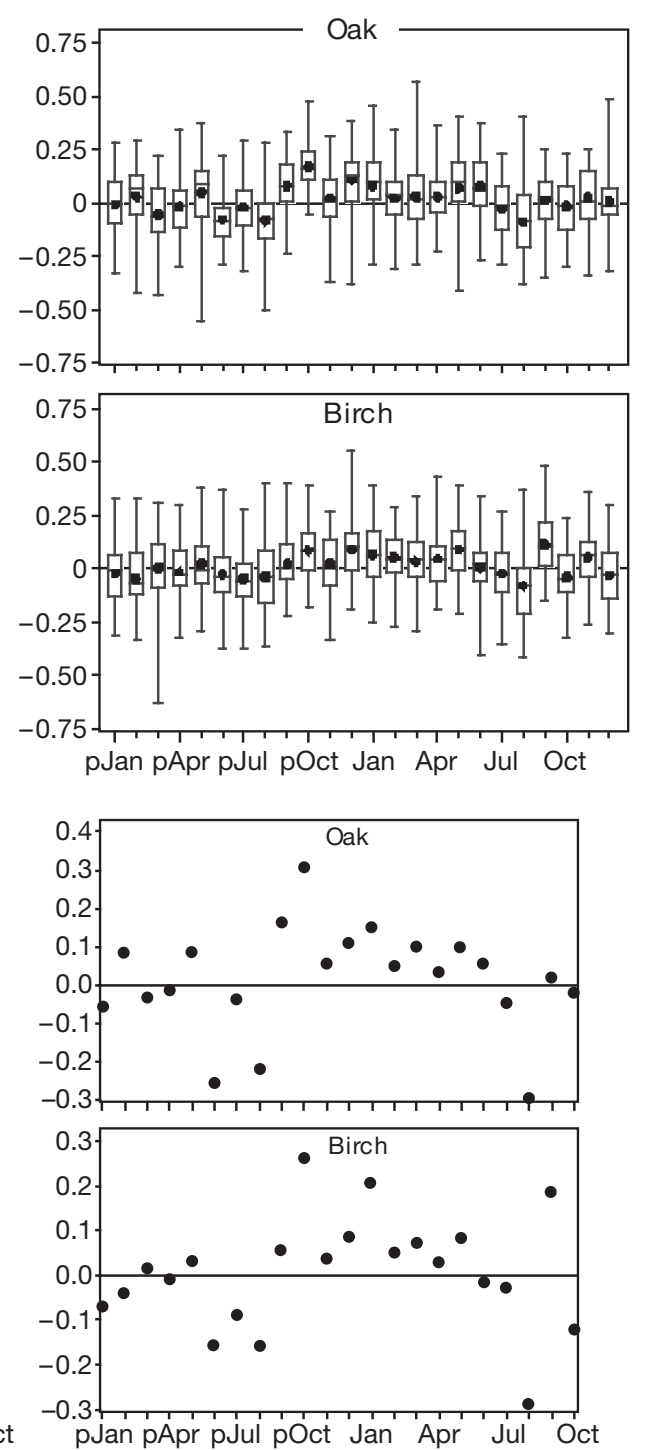

Fig. 5. Pearson correlation coefficients ( $r$ ) of monthly sums of precipitation ( $p=$ previous year) and the onset dates of leaf colouring. In boxes, $\mathbf{\|}=$ mean, horizontal line = median. (a) Set A: data of single phenological stations near meteorological stations, (b) Set B: spatially averaged phenological means near meteorological stations, and (c) Set C: national phenological means and national meteorological means 
a
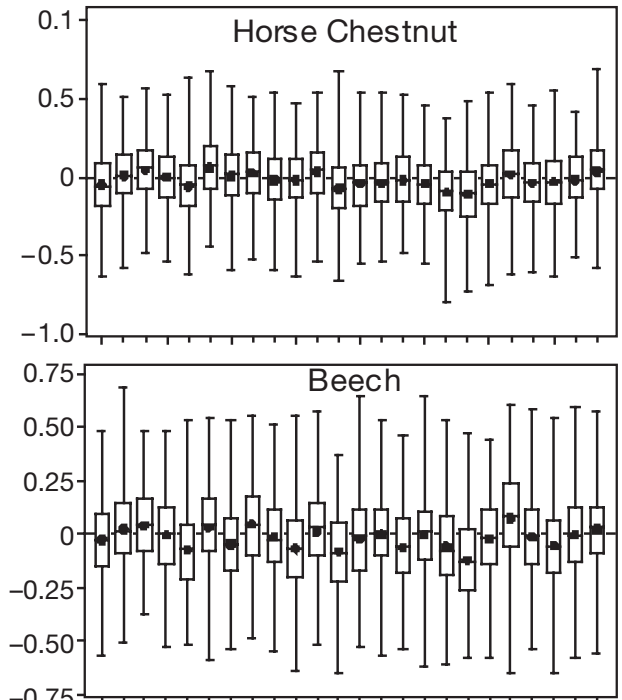

pJan pApr pJul pOct Jan Apr Jul Oct
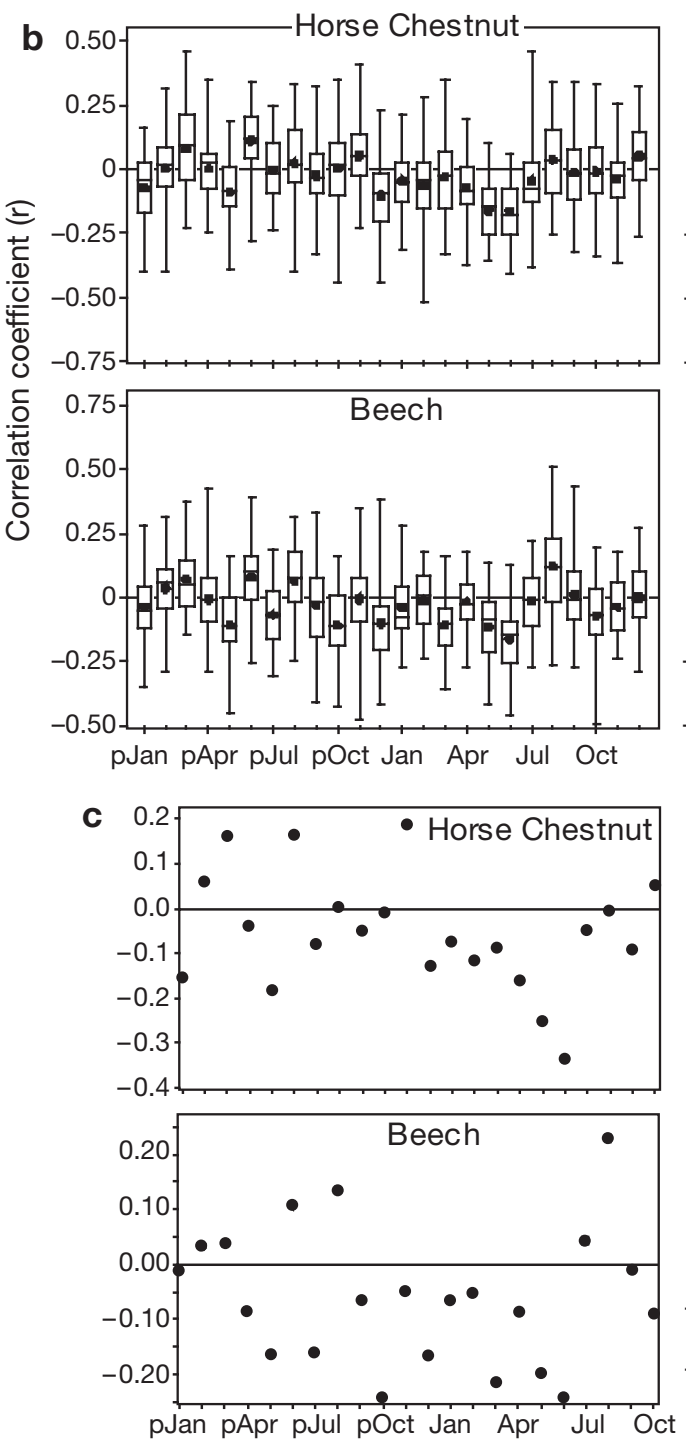
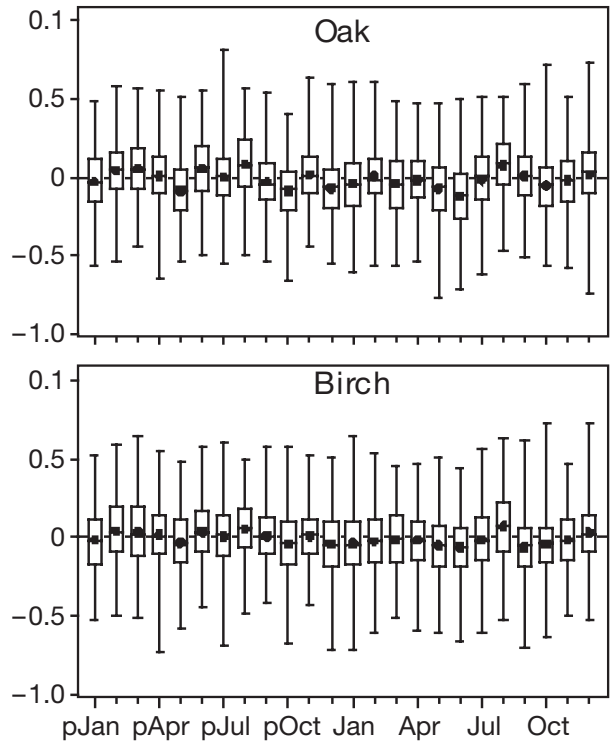

pJan pApr pJul pOct Jan Apr Jul Oct
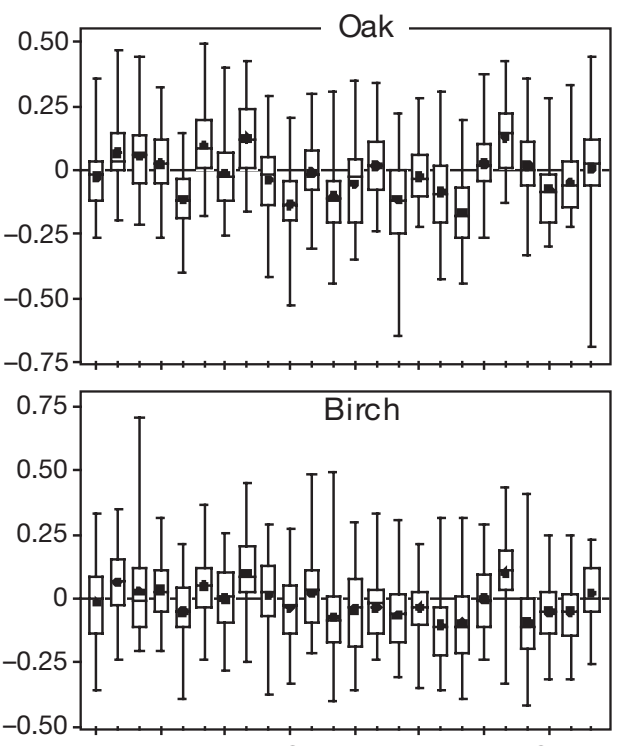

pJan pApr pJul pOct Jan Apr Jul Oct
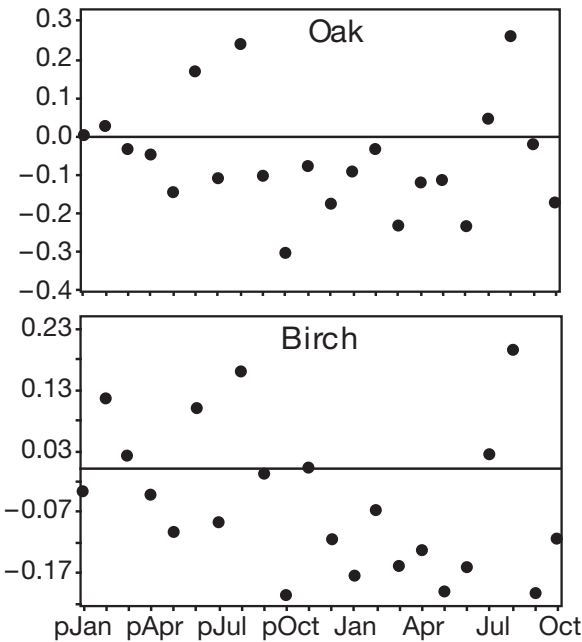

Fig. 6. Pearson correlation coefficients (r) of monthly number of dry days ( $p=$ previous year) and the onset dates of leaf colouring. In boxes, = mean, horizontal line = median. (a) Set A: data of single phenological stations near meteorological stations, (b) Set B: spatially averaged phenological means near meteorological stations and (c) Set C: national phenological means and national mean of number of dry days 
matched with observed leaf colouring dates. The results of the threshold approach (first drop below thresholds of 5 and $8^{\circ} \mathrm{C}$ ) are summarised in Fig. 4 $\left(\mathrm{FD}_{\text {mean5 }}\right.$ and $\left.\mathrm{FD}_{\text {mean8 }}\right)$. We enlarged the definition to a drop below these threshold temperatures for 5 consecutive days, which corresponds to the $5^{\circ} \mathrm{C}$ agricultural (FAO 1978-1981) and $8^{\circ} \mathrm{C}$ forestry definitions (Hartmann \& Schnelle 1970). The results were quite similar, and the results for a threshold of $8^{\circ} \mathrm{C}$ are displayed in Fig. 7. Leaf colouring dates were not strongly related to these vegetation end dates. In the single station analyses (Fig. 6a), the lowest correlations coefficients were $\mathrm{r}=-0.71$ for birch, -0.66 for beech, -0.59 for oak and -0.54 for horse chestnut; the highest were 0.63 (birch), 0.62 (horse chestnut), 0.62 (beech) and 0.57 (oak). In the climate station analyses (Fig. 7b), the extreme values of $\mathrm{r}$ were lower $(\mathrm{r}<|0.4|)$. The values of $r$ for the German mean of leaf colouring and end of vegetation period were $<|0.1|$ for all species; therefore we conclude that there is hardly any correlation between the parameters tested and leaf colouring.

\subsection{Differentiation by the sign of leaf colouring trend}

Our last approach was to divide Set A into phenological stations where leaf colouring time series exhibited a significant positive trend, which corresponds to delayed leaf colouring, and those stations with a significant negative trend. Here we examined whether explicit trends were related to higher explanatory values of the triggering variables tested. Only phenological stations with at least $30 \mathrm{yr}$ of leaf colouring observations and a significant (positive or negative) trend were correlated with the same meteorological parameters as before. We included 31 stations with a positive trend $(\mathrm{A}+)$ and 28 stations with a negative trend (A-) for horse chestnut, 36 stations $\mathrm{A}+$ and 18 stations $\mathrm{A}$ - for beech, 48 stations $\mathrm{A}+$ and 8 stations $\mathrm{A}-$ for oak, and 37 stations $\mathrm{A}+$ and 12 stations $\mathrm{A}-$ for birch.

In Fig. 8, the correlation coefficients between leaf colouring dates and all the meteorological factors, except drought, are plotted. Neither stations with positive leaf colouring trends nor stations with negative trends showed a specific pattern. In order to verify this finding, we systematically checked, for all parameters, whether the mean correlation coefficients of the 2 groups differed from each other using 2 sample $t$-tests. Out of 22 monthly temperatures tested for 4 species, 32 comparisons of mean correlation coefficients did not show any difference between the 2 groups. However, in 56 cases, the mean correlation coefficients for stations with positive and negative trends displayed significant differences. These results are most difficult to interpret as there is almost no consistency between
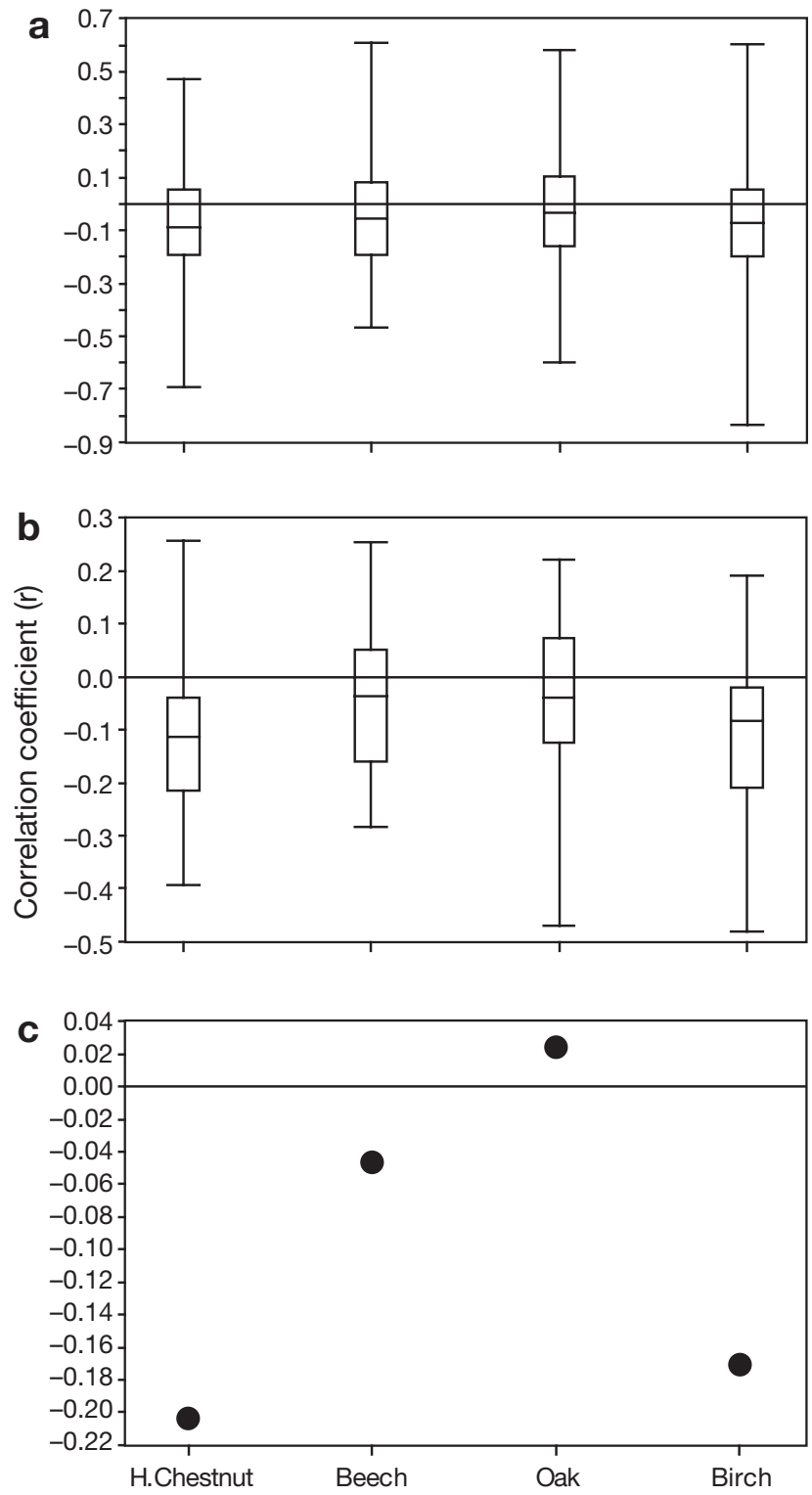

Fig. 7. Pearson correlation coefficients (r) of the end of vegetation period in forestry (drop of mean air temperature below $8^{\circ} \mathrm{C}$ on 5 subsequent days, modified after Hoffmann \& Schnelle 1970) and onset dates of leaf colouring. (a) Set A: data of single phenological stations near meteorological stations, (b) Set B: spatially averaged phenological means near meteorological stations, and (c) Set C: national phenological means and national mean of end of vegetation period

the 4 species studied (e.g. September of the current year displayed significantly different correlation coefficients for horse chestnut and beech whereas there were no significant differences for oak and birch). Only the months of January, March, May and August displayed significant differences in their correlation coefficients between stations with positive and negative trends for all species. 

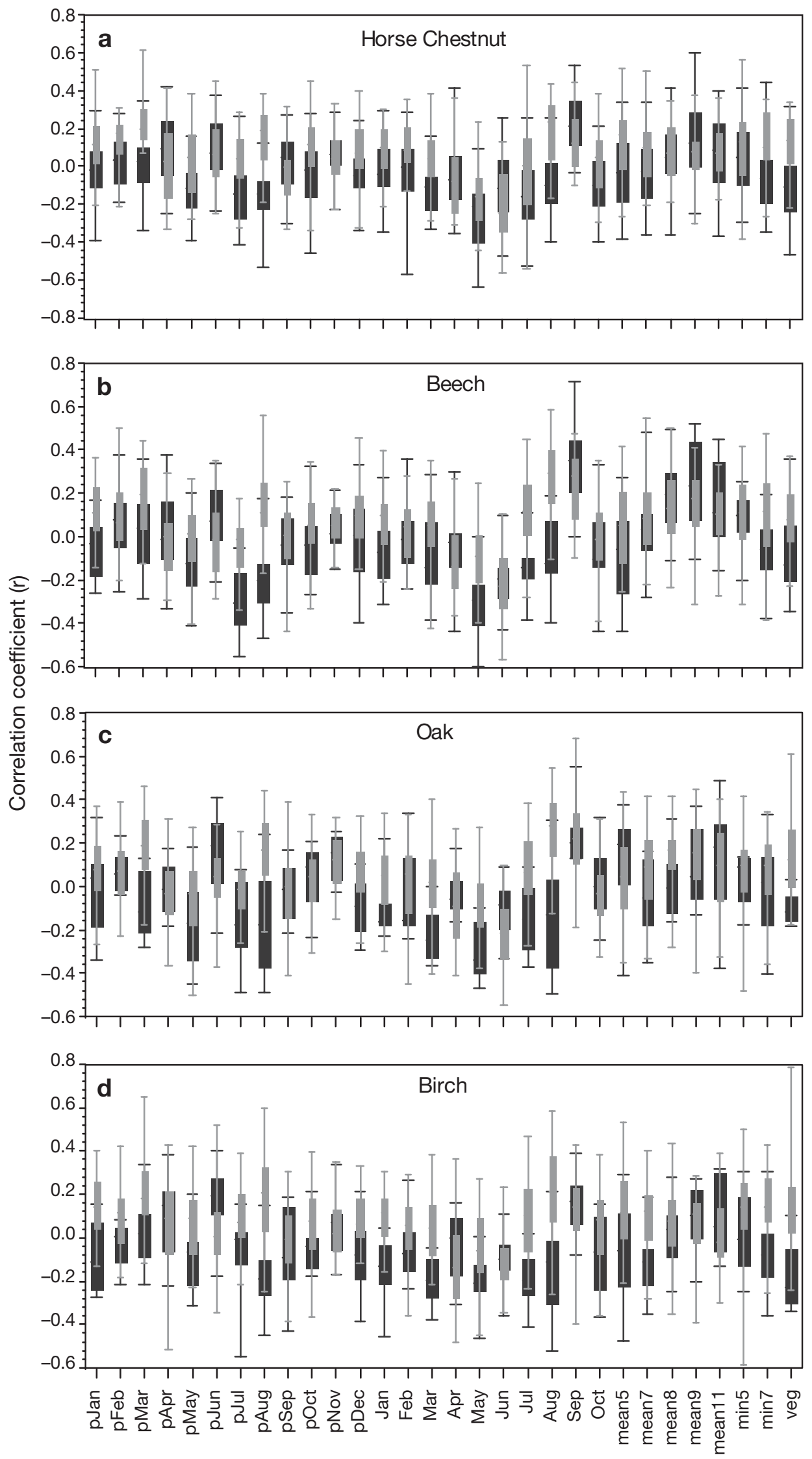

Fig. 8. Pearson correlation coefficients (r) of onset dates of leaf colouring and parameters of Figs. $2,3 \& 6$, divided up for stations with positive (grey) and negative (black) significant trends in time series $>30$ yr (monthly mean temperatures); $\mathrm{p}=$ previous year; mean11 = $\mathrm{FD}_{\text {mean }}<11^{\circ} \mathrm{C}$; mean9 $=\mathrm{FD}_{\text {mean }}<$ $9^{\circ} \mathrm{C}$, mean8 $=\mathrm{FD}_{\text {mean }}<8^{\circ} \mathrm{C}$; mean7 $=\mathrm{FD}_{\text {mean }}<7^{\circ} \mathrm{C}$; mean5 $=\mathrm{FD}_{\text {mean }}<$ $5^{\circ} \mathrm{C}_{i} \min 5=\mathrm{FD}_{\min }<5^{\circ} \mathrm{C}_{i} \min 7=$

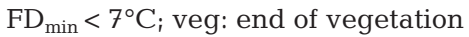
period modified after Hoffmann \& Schnelle (1970) 


\section{DISCUSSION AND CONCLUSIONS}

There is no complete and coherent model for the timing of observed leaf colouring of deciduous trees in temperate zones. Some biosphere models have a procedure to end the vegetation period of deciduous broadleaf trees in temperate regions: The IBIS biosphere model, for example, uses the common hypothesis that mean daily temperature $<5^{\circ} \mathrm{C}$ leads to leaf shedding (Foley et al. 1996); more complex modules use a combination of soil and air temperature to calculate the annual course of the leaf area index (LAI) (Knorr 2000); the BIOME BGC applies an $11 \mathrm{~d}$ mean of daily mean temperature, and leaf shedding is initiated when the temperature drops below $11^{\circ} \mathrm{C}$ with a day length $<10.92 \mathrm{~h}$ or when the smoothed temperature falls $<2^{\circ} \mathrm{C}$ (White et al. 1997). These biosphere models determine the day on which leaves are shed, but none of them is designed to predict the onset of leaf colouring of a specific deciduous tree species in temperate regions.

On the other hand, numerous hypotheses exist in the literature; a fact that might reflect the complexity of the problem. No test has ever systematically checked the statistical relationship to leaf colouring dates on a national scale. We tested all those hypotheses listed in Table 1, except constant day length. With a constant day length, leaf colouring should always occur at the same day of the year in defined latitudinal bands, which is obviously not the case.

There are some possible reasons why triggers of autumn colouring, contrary to leaf unfolding, are generally difficult to identify. (1) The phenological phase 'leaf colouring' is obviously less easy to recognise than the first 3 green leaves in spring, because the phase definition refers to $50 \%$ of all leaves coloured, including leaves both on branches and on the ground. The variation among individual trees at comparable or identical sites is much higher than in spring (Baumgartner 1952). (2) There is always the possibility of 'green leaf fall', if temperatures and water supply in autumn do not lead to a visible change in leaf colour, and then observers can hardly note the date for the end of the vegetation period. The age of the tree and internal influences are more important for the timing of leaf colouring than external influences (e.g. Baumgartner 1952, Junges 1962, Brügger 1998).

Our analyses underline that leaf colouring might be triggered by factors other than temperature alone. However, none of the factors tested exhibited explanatory power. Results show a vast station-to-station variability, therefore they do not 'prove' any of the hypotheses concerning warm autumn weather and sufficient water supply (Seyfert 1955, 1966) or accelerated leaf colouring through high autumn temperatures
(Schulze 1970). The hypotheses related to the crossing of certain threshold temperatures cannot be confirmed by our dataset on leaf colouring dates, thus rebutting the hypotheses of Baumgartner (1959) and Schnelle (1952). Modified threshold temperatures describing the end of the vegetation period show hardly any correlation with leaf colouring, therefore we can reject the hypothesis of Hartmann \& Schnelle (1970). In addition, none of the monthly sums of precipitation nor the number of dry days per month produced meaningful correlations; these proxies for soil moisture did not offer a convincing trigger for leaf colouring. This may be because they are an inadequate proxy or because water supply is not a trigger in these climatic conditions.

We conclude that, for mid latitudes, the triggers of leaf colouring are a complex mixture of several interacting factors. Only the hypothesis of Freitag (1987) is partially supported, because among the factors of slightly higher influence are: (1) mean monthly August to September temperature $(r>0.4$ for all species in Set C) and (2) mean monthly May/June temperatures. However, due to the vast station-to-station variability, these results do not 'prove' any of the hypotheses between monthly temperature and onset of leaf colouring.

Further methodological issues concerning hypotheses related to e.g. soil properties and radiation were not undertaken due to the lack of relevant auxiliary data (radiation, soil type, exposure or slope). These differences in local conditions may be a reason for the lack of significant results. However, we know from analyses of spring phenology that it is possible to compare heterogeneous sites and genetically non-identical plants, especially if using a large number of stations. Thus site differences alone should not cause the level of 'white noise' found in autumn phenology. Another problem in our analyses is that while monthly mean temperatures are a commonly used explanatory variable in phenology they do not represent a physiological period.

Further studies on possible triggering factors could include experimental approaches to supply auxiliary data and to scale down the time-span of influencing factors (e.g. monthly to weekly data). Additional studies on our datasets (not shown) suggest that there was no regional pattern in the correlation coefficients of the different analyses. Moreover, we tested temperature sums (starting in March, with thresholds of either 8 or $5^{\circ} \mathrm{C}$ ) and the number of days above thresholds, but these did not produce meaningful results.

Building a multiple linear model for leaf colouring is hampered by the lack of significant and relevant parameters and the strong interrelation of those parameters that have some importance (e.g. dates when different threshold temperatures are crossed and mean monthly temperatures, temperature and precipitation). 
Although the correlations did not reveal triggers for leaf colouring, the best ones can be integrated in a multiple linear regression model with 3 parameters; this constitutes a good compromise between including relevant factors and avoiding 'statistical' ballast.

In a best $\mathrm{R}^{2}$ procedure, the mean onset of leaf colouring in Germany was explained by 3 parameters which were selected out of all available parameters.

For 3 phases, only mean monthly temperatures were used: for beech $\left(\mathrm{R}^{2}=0.56\right)$ and oak $\left(\mathrm{R}^{2}=0.56\right)$, June, August and September monthly mean temperatures were included, for horse chestnut $\left(R^{2}=0.68\right)$, May, June and September mean temperatures. For birch $\left(R^{2}=0.49\right)$, the number of dry days in September were incorporated alongside August and September mean temperatures. Regressions were:

- Horse chestnut leaf colouring [day of the year] = $289.16+\left(-1.03 \times\right.$ mo_5 $\left.\left[{ }^{\circ} \mathrm{C}\right]\right)+\left(-0.96 \times\right.$ mo_6 $\left.\left[{ }^{\circ} \mathrm{C}\right]\right)+$ $\left(1.14 \times\right.$ mo_9 $\left.\left[{ }^{\circ} \mathrm{C}\right]\right)$

- Beech leaf colouring [day of the year] $=264.86+$ $\left(-1.30 \times\right.$ mo_6 $\left.\left[{ }^{\circ} \mathrm{C}\right]\right)+\left(1.04 \times\right.$ mo_8 $\left.\left[{ }^{\circ} \mathrm{C}\right]\right)+(1.56 \times$ mo_9 [ $\left.\left.{ }^{\circ} \mathrm{C}\right]\right)$

- Oak leaf colouring [day of the year] $=269.06+$ $\left(-1.34\right.$ mo_6 $\left.\left[{ }^{\circ} \mathrm{C}\right]\right)+\left(1.33 \mathrm{mo} 8\left[{ }^{\circ} \mathrm{C}\right]\right)+\left(1.31 \mathrm{mo} \_9\left[{ }^{\circ} \mathrm{C}\right]\right)$

- Birch leaf colouring [day of the year] $=254+(0.68$ mo_8 $\left.\left[{ }^{\circ} \mathrm{C}\right]\right)+\left(1.45\right.$ mo_9 $\left.\left[{ }^{\circ} \mathrm{C}\right]\right)+(-0.35$ ndry_9 [no. of days] $)$

In general, monthly mean temperature for May and June, as well as the number of dry days in September, had negative regression coefficients, whereas monthly mean temperature in August and September had positive coefficients. This means that a warm August and September delayed leaf colouring, but a dry September as well as warm May and June led to an advanced leaf colouring.

Our results show that it is, in principle, possible to build a model for a whole region, or even on a national scale, but due to the white noise in the datasets containing single stations as well as climate station information, it is not possible to design a valid overall model that is site-specific.

Acknowledgements. We thank the German Meteorological Service for providing the phenological and meteorological data analysed in this work. We thank Tim Sparks for his valuable comments.

\section{LITERATURE CITED}

Arora VK, Boer G J (2005) A parameterization of leaf phenology for the terrestrial ecosystem component of climate models. Global Change Biol 11:39-59

Baumgartner A (1950) Methodisches zur Darstellung des Witterungseinflusses auf den Verlauf der Pflanzenentwicklung; erläutert an den phänologischen Beobachtungen 1974 in Bad Kissingen. Meteorol Rundsch 3:217-221

Baumgartner A (1952) Zur Phänologie von Laubhölzern und ihre Anwendung bei lokalklimatischen Untersuchungen. Ber Dtsch Wetterdienst US-Zone 42:69-73

Brügger R (1998) Phänologie von Buche und Fichte: Beobachtung, Variabilität, Darstellung und deren Nachvollzug in einem Modell. Geogr Bern G49

Chmielewski FM, Rötzer T (2001) Response of tree phenology to climate change across Europe. Agric For Meteorol 108: $101-112$

Chuine I, Cour P, Rousseau DD (1999) Selecting models to predict the timing of flowering of temperate trees: implications for tree phenology modelling. Plant Cell Environ 22: $1-13$

Chuine I, Kramer K, Hänninen H (2003) Plant development models. In: Schwartz MD (ed) Phenology: an integrative environmental science. Kluwer Academic Publishers, Dordrecht, p 217-235

Defila C, Clot B (2001) Phytophenological trends in Switzerland. Int J Biometeorol 45:203-207

Deutscher Wetterdienst (1991) Anleitung für die phänologischen Beobachter des deutschen Wetterdienstes (BAPH). Dtsch Wetterdienst 17 (VuB17)

EEA (2004) Impacts of Europe changing climate. An indicator-based assessment. European Environment Agency, Copenhagen (Denmark), Report 2/2004

FAO (1978-1981) Reports of the agro-ecological zones project. Vols 1 to 4 . World soil resources reports No. 48/1 (1978), 48/2 (1978), 48/3 (1981), 48/4 (1980). Food and Agriculture Organization, Rome

Foley JA, Prentice IC, Ramankutty N, Levis S, Pollard D, Sitch S, Haxeltine A (1996) An integrated biosphere model of land surface processes, terrestrial carbon balance, and vegetation dynamics. Global Biogeochem Cycles 10: 603-628

Freitag E (1987) Auswirkungen von Klimaänderungen auf den Entwicklungsrhythmus der Pflanzen für historische Zeiträume. Schlussbericht zum BMFT-Förderungsvorhaben KF 2008. Deutscher Wetterdienst, Offenbach am Main

Hartmann FK, Schnelle F (1970) Klimagrundlagen natürlicher Waldstufen und ihrer Waldgesellschaften in deutschen Mittelgebirgen. Gustav Fischer Verlag, Stuttgart

Hänninen H (1990) Modelling bud dormancy release in trees from cool and temperature regions. Acta For Fenn 213:1-47

IPCC (2001) McCarthy JJ, Canziani OF, Dokken DJ, White KS (eds) Climate change 2001: impacts, adaptation and vulnerability. Contribution of Working Group II to the Third Assessment Report of the Intergovernmental Panel on Climate Change. Cambridge University Press, Cambridge

Junges W (1962) Die phänologische Winterruhe in einer Population der Rosskastanie. Angew Meteorol 4:113-119

Käräpati L, Varga G (1964) Zusammenhang zwischen Gestaltung der Vegetation und Wasserführung im Mustergelände Gadi-sziget-relationship between plant growth and regime on Gad Island Research Centre. Hidrologiai Kazlany 3 (available at: www.iad.gs/content/library/artikel/ artikel2.php)

Knorr W (2000) Annual and interannual $\mathrm{CO}_{2}$ exchanges of the terrestrial biosphere: process based simulations and uncertainties. Glob Ecol Biogeogr 9:225-252

Koike T (1990) Autumn coloring, photosynthetic performance and leaf development of deciduous broad-leaved trees in relation to forest succession. Tree Physiol 7:21-32

Kramer K (1995) Phenotypic plasticity of the phenology of seven European tree species in relation to climatic warming. Plant Cell Environ 18:93-104

Maede A (1952) Bemerkungen zur Vereinfachung des phäno- 
logischen Meldeprogramms. Ber Dtsch Wetterdienst USZone 42:110-114

Matsumoto K, Ohta T, Irasawa M, Nakamura T (2003) Climate change and extension of the Ginkgo biloba L. growing season in Japan. Global Change Biol 9:1634-1642

Menzel A (1997) Phänologie von Waldbäumen unter sich ändernden Klimabedingungen-Auswertung der Beobachtungen in den Internationalen Phänologischen Gärten und Möglichkeiten der Modellierung von Phänodaten. Forstliche Forschungsberichte München Nr. 164

Menzel A, Fabian P (1999) Growing season extended in Europe. Nature 397:659

Menzel A, Estrella N (2001) Plant phenological changes. In: Walther GR, Burga CA, Edwards PJ (eds) 'Fingerprints' of climate change-adapted behaviour and shifting species ranges. Kluwer Academic/Plenum Publishers, New York, p $123-137$

Menzel A (2002) Phenology: its importance to the global change community. Clim Change 54:379-385

Menzel A (2003) Plant phenological anomalies in Germany and their relation to air temperature and NAO. Clim Change 57:243-263

Pfau R (1964) Varianz- und korrelationsanalytische Untersuchungen an phänologischen Phasen. Meteorol Rundsch 17:113-122

Root TL, Price JT, Hall KR, Schneider SH, Rosenzweig C, Pounds JA (2003) Fingerprints of global warming on wild animals and plants. Nature 421:57-60

Schaber J (2002) Phenology in Germany in the 20th century: methods, analyses and models. PhD thesis, University of Potsdam

Editorial responsibility: Helmut Mayer, Freiburg, Germany
Schnelle F (1952) Über die Abhängigkeit der Laubverfärbung von der Temperatur. Ber Dtsch Wetterdienst US-Zone 38: $227-228$

Schnelle F (1979) Phänologische Spezialkarten der Laubentfaltung und Laubverfärbung von Roßkastanie, Weißbirke, Rotbuche und Stieleiche auf dem Gebiet der Bundesrepublik Deutschland. Fachliche Mitt Amt für Wehrgeophys, Traben-Trarbach

Schulze ED (1970) Der $\mathrm{CO}_{2}$-Gaswechsel der Buche (Fagus sylvatica L.) in Abhängigkeit von den Klimafaktoren im Freiland. Flora 159:177-232

Seyfert F (1955) Eintritt phänologischer Phasen und auslösende Wetterlagen. Angew Meteorol 2:183-190

Seyfert F (1966) Ein Beitrag zur Prognose phänologischer Daten. Abh Meteorol Dienst DDR Nr 80. Akademie Verlag, Berlin

Seyfert F (1970) Phänologische Studien aus dem Erzgebirge. Abh Meteorol Dienst DDR Nr 91. Akademie Verlag, Berlin

Sparks TH, Menzel A (2002) Observed changes in seasons: an overview. Int J Climatol 22:1715-1725

Sitte P, Weiler EW, Kadereit J, Bresinsky A, Körner C (2002) Strasburger-Lehrbuch der Botanik. Spektrum Akademischer Verlag, Heidelberg

Walther GR, Post E, Convey P, Menzel A and 5 others (2002) Ecological responses to recent climate change. Nature 416:389-395

White MA, Thornton PE, Running SW (1997) A continental phenology model for monitoring vegetation responses to interannual climatic variability. Global Biogeochem Cycles 11:217-234

Submitted: March 27, 2006; Accepted: July 11, 2006 Proofs received from author(s): October 15, 2006 